\title{
Resource Relatedness and Its Effect on the Performance of Parent Firm and Foreign Subsidiary
}

\author{
Rani Kumar
}

\section{ABSTRACT}

\begin{abstract}
The parent-subsidiary relation is attracting increasing academic interest. However, prior studies on the parent-subsidiary relatedness did not clearly demonstrate the effect of resource relatedness between the parent firm and its subsidiaries on the performance of parent and foreign subsidiaries. Building on resource-based and knowledge-based views, we investigated the effect of resource relatedness on the performance of parent firm and foreign subsidiary. We discussed the theoretical foundations and main accomplishments of prior studies. We developed a conceptual framework and hypothesis in order to close the existing research gap in the topic of interest. We claimed that resource relatedness has a positive impact on the performance of foreign subsidiary, while its effect on the performance of the parent firm can be both positive and negative.
\end{abstract}

Keywords: Firm performance; International business; Relatedness.

\author{
Submitted : July 27, 2021 \\ Published : August 18, 2021 \\ ISSN: $2507-1076$ \\ DOI: $10.24018 /$ ejbmr.2021.6.4.998 \\ R. Kumar* \\ D. Y. Patil University, School of \\ Management, India. \\ (e-mail: rani.kumar.rku@gmail.com) \\ *Corresponding Author
}

\section{INTRODUCTION}

Diversification in international setting refers to a firm diversifies into overseas geographic markets, either through foreign direct investments or through exports. There could be potential benefits through diversification for a firm such as exploitation of firm-specific advantage, learning foreign knowledge, and cheap inputs in overseas countries [1]. When the transaction costs are high, Firms usually exploit a firmspecific advantage in foreign countries through internalizing their valuable intangible assets instead of selling them via the imperfect external market. To maximize profits for the headquarters, the foreign subsidiary is regarded as an extension of the multinational enterprise (MNE) structure and the place where the intangible assets are exploited. However, there could be potential costs through foreign expansion such as initial sunk costs, unfamiliarity with foreign countries, and greater complexity in global coordination [2].

Resource is a vital foundation for firms' competitive advantage. In the context of internationalization, researchers argued that business relatedness at the level of parentsubsidiary plays a major role in the performance of multinational corporations since it may affect MNEs' global strategies. Prior studies on the parent-subsidiary relatedness do not clearly demonstrate the effect of resource relatedness between the parent firm and its subsidiaries on the performance of both the parent and foreign subsidiary.

The resource-based view, which conceptualizes the firm as a bundle of resources [3], largely influences this research stream. The resource-based view contends that a firm's motivation to diversify is to maximize firm resources. A firm's understanding of its current resources provides a starting point for understanding vital issues about its growth and diversification strategies [4]. Accordingly, RBV submits that firms' resources and capabilities significantly influence a firm's level of diversification and its performance. Given this, based on the resource-based view, this study investigates the critical issue of resource relatedness in multinational enterprise management and further examines how resource relatedness affects the performance of both the parent firm and foreign subsidiary.

In this study, resource relatedness is defined as a similarity between the parent resources and those of the foreign subsidiary. The degree of resource relatedness can influence the efficiency of exploiting valuable resources and thus, the performance of MNEs. In this vein, this study investigates under what conditions resource relatedness leads to the superior performance of the firm. We will explore this question regarding both the parent firm and foreign subsidiary perspective.

Although foreign subsidiary can be a source of valuable resources to the parent firm and helps it to develop new capabilities, it may only provide the parent firm the opportunity to obtain its needed resources. Thus, the parent firm may need to acquire its needed resources by involving in foreign investment activities and developing effective resource acquisition mechanisms to ensure the effective acquisition of needed resources from its foreign subsidiary. In this regard, we considered the level of parent involvement as a moderator and investigate its impact on the relationship between resource relatedness and the performance of the parent firm.

In addition, previous studies have highlighted that similar business backgrounds, which may be driven by resource relatedness between the parent firm and foreign subsidiary, may result in the existence of compatible knowledge between them. This can help the firm to transfer strategic resources and practices more effectively to the foreign subsidiary, thus 
increasing its sustainable competitive advantage and performance. In this study, we explored the role played by resource relatedness on the performance of a foreign subsidiary.

This study contributes to the existing literature by emphasizing the role of resource relatedness in parentsubsidiary relation research. We investigate the role that resource relatedness may play on the performance of both the parent firm and foreign subsidiary, thus adding to previous research that examined this relationship by focusing on different factors like coordination mechanism, control mechanism and subsidiary autonomy.

\section{LITERATURE REVIEW}

The strategic management literature has largely adopted Resource-Based View (RBV) to inform international diversification [5]. According to the resource-based perspective, market-diversified firms seek to use internal resources and capabilities to exploit market imperfections that exist across global regions and countries [6]. International diversification enables the sharing of core competencies among different geographic markets [7]. The underlying assumption within RBV regarding international diversification, is the heterogeneity of firm resources [8]. Several researchers suggest that a firm views international diversification as a dynamic, long-term process in which the firm applies its capabilities and learning from previous entries to future entries [9]. The resource-based view also puts forth the proposition that the capability to learn maybe a tacit resource fundamental to a firm's competitive advantage [10].

The resource-based view suggests that a firm is a bundle of heterogeneous resources, and its competitive advantage draws from possessing resources that are valuable, rare, imperfectly imitable, and hard to substitute [11]. Previous studies indicated that the parent firm (foreign subsidiary) can access these resources through the foreign subsidiary (parent firm) [12], [13]. [14] in his paper argued that resource relatedness between the parent and subsidiary can influence the parent performance in obtaining needed resources from its foreign subsidiary. Although resource relatedness is important for both parent and foreign subsidiary performance, previous studies have not investigated the subject thoroughly [15].

We can categorize the parent-subsidiary literature into two main categories. In the first category, researchers investigated the effect of parent-subsidiary relation on the parent firm performance. Studies under this category mainly examined the effects of headquarters' (HQ) governance structure communication and coordination mechanisms, control mechanisms, and subsidiary's autonomy on the parent firm performance [15]-[19]. Table I summarizes the related articles.

The second category explored the effect of parentsubsidiary relation on foreign subsidiary performance. In this research stream, scholars investigated various aspects like subsidiary's autonomy [2], [14], [20]-[23] on the performance of foreign subsidiary. Table II shows the related articles.
TABLE I: PARENT-SUBSIDIARY RELATION AND PARENT FIRM PERFORMANCE

\begin{tabular}{|c|c|c|}
\hline \multicolumn{3}{|c|}{ PERFORMANCE } \\
\hline Papers & Type of relation & $\begin{array}{l}\text { Parent Firm } \\
\text { Performance }\end{array}$ \\
\hline$[15]$ & Communication & $\begin{array}{l}\text { Reverse knowledge } \\
\text { transfer (Subsidiary } \\
\text { to parent firm) }\end{array}$ \\
\hline$[16]$ & Control mechanism & $\begin{array}{l}\text { Reverse knowledge } \\
\text { transfer (Subsidiary } \\
\text { to parent firm) }\end{array}$ \\
\hline$[17]$ & $\begin{array}{l}\text { Diversification strategy, } \\
\text { governance system }\end{array}$ & $\begin{array}{l}\text { Financial } \\
\text { performance }\end{array}$ \\
\hline$[18]$ & Governance structure & $\begin{array}{c}\text { Financial } \\
\text { performance }\end{array}$ \\
\hline [19] & $\begin{array}{l}\text { Subsidiary autonomy, } \\
\text { Coordination } \\
\text { mechanism }\end{array}$ & $\begin{array}{l}\text { Reverse knowledge } \\
\text { transfer (Subsidiary } \\
\text { to parent firm) }\end{array}$ \\
\hline
\end{tabular}

TABLE II: PARENT-SUBSIDIARY RELATION AND FOREIGN SUBSIDIARY PERFORMANCE

\begin{tabular}{|c|c|c|}
\hline Papers & Type of relation & $\begin{array}{l}\text { Parent Firm } \\
\text { Performance }\end{array}$ \\
\hline [14] & $\begin{array}{l}\text { Information flow, } \\
\text { Local responsiveness }\end{array}$ & $\begin{array}{c}\text { Financial } \\
\text { performance }\end{array}$ \\
\hline$[21]$ & $\begin{array}{l}\text { Ownership strategy, } \\
\text { Institutional distance }\end{array}$ & Survival \\
\hline$[20]$ & $\begin{array}{l}\text { HQ attention, } \\
\text { Subsidiary stage } \\
\text { choice }\end{array}$ & $\begin{array}{c}\text { Financial } \\
\text { performance }\end{array}$ \\
\hline$[22]$ & $\begin{array}{c}\text { Subsidiary } \\
\text { embeddedness }\end{array}$ & $\begin{array}{l}\text { HQ involvement in } \\
\text { innovation } \\
\text { transfer process }\end{array}$ \\
\hline$[2]$ & $\begin{array}{c}\text { Ownership strategy, } \\
\text { Firm-specific } \\
\text { intangible assets }\end{array}$ & $\begin{array}{c}\text { Financial } \\
\text { performance }\end{array}$ \\
\hline$[23]$ & Subsidiary autonomy & $\begin{array}{c}\text { Firm Performance } \\
\text { (meta-analysis) }\end{array}$ \\
\hline
\end{tabular}

According to the existing literature, relatively little research has been conducted to investigate the relationship between resource relatedness and performance of parent and foreign subsidiary. In order to fill this gap by utilizing the resource-based view, we tried to answer the question of why and how resource relatedness has an impact on the parent and subsidiary performance. We argued that resource relatedness can have a reciprocal effect. The parent firm can help the foreign subsidiary by transferring necessary resources, which then enables the subsidiary to develop new technologies and provide more opportunities for the parent firm to obtain valuable resources.

In the following section, the developed hypothesis is discussed in detail.

\section{HYPOTHESIS DEVELOPMENT}

Understanding the role of resource relatedness, at the parent-subsidiary level, on the performance and survival of a foreign subsidiary is widely recognized as a seminal research agenda in strategic management. In the international diversification setting, scholars argued that due to the liability of foreignness, knowledge asymmetry and uncertainty undermine the realization of expected synergies. Thus, the performance and survival of a foreign subsidiary can be affected by diversification [24]. Moreover, firms diversifying into the businesses that are departed from their current business typically experience greater uncertainty. In this case, 
the diversification process can substantially increase the level of uncertainty due to the fact that the firm is being exposed to both the risks of entry into a foreign country and the risks of entering into a new business. As a result, resources, processes, and competencies cannot be shared among unrelated businesses, and the parent firm is unable to pass the required resources and competencies to its foreign subsidiary.

Conversely, with greater resource relatedness, the broader set of resources and competencies can be passed to the subsidiary [25]. Thus, it increases the potential synergies at product, technological, and market-level between the parent firm and its foreign subsidiary. Moreover, due to related business background, this knowledge domain can be more effectively transferred, which eventually results in increasing of knowledge compatibility between parent and foreign subsidiary. Also, the related business domain implies the alignment of the parent firm and its foreign subsidiary in terms of business logic and cognitive structure [26]. As a result, the transfer of knowledge and the parent firm's specific advantages can be facilitated in the case of greater parentsubsidiary resource relatedness, which has a positive impact on the performance of a foreign subsidiary.

In this paper, we extend these arguments and propose that since with greater relatedness, both the parent firm, by being able to transfer the knowledge to its subsidiary, and the subsidiary, by being able to acquire the parent firm-specific advantages, resource relatedness enhance the subsidiary competitive advantage and thus increase its performance and likelihood of survival. Therefore, we proposed the following hypothesis:

Hypothesis 1 (H1). Resource relatedness between parent and foreign subsidiary has a positive impact on the subsidiary's performance and survival likelihood.

In addition, we can investigate the effect of resource relatedness on the performance of the parent firm. Since resource relatedness makes the parent-subsidiary coordination take place more effectively and help the parent firm to allocate its resources more efficiently, it enables the parent firm to respond better to market uncertainties, integrate similar resources resulting in core competence, allows for more efficient knowledge sharing, and enhancing its competitive advantage.

From the opposite point of view, considering the economy of scope, a high level of resource dissimilarity enables the parent firm to develop new technologies through the combination of different resources to respond to the market need more efficiently. It also implies the abundance of complementary resources that stimulate the parent firm to broaden its breadth of search. Ultimately, this can yield to develop novel solutions that enhance the competitive advantage of the parent firm. Hence, the effect of resource relatedness on the performance of the parent firm is twosided: on the one hand, it enables the parent firm to efficiently coordinate and effectively integrate the resources. On the other hand, economies of scope and complementary resources help the parent firm to enhance its competitive advantage.

Hypothesis $2(\mathrm{H} 2)$. Resource relatedness between parent and foreign subsidiary has both positive and negative impact on the performance of the parent firm.

\section{CONCLUSION}

In this paper, we investigated the parent-subsidiary relation through the resource relatedness and explored its possible impacts on the performance of both parent firm and foreign subsidiary. We argued that the greater relatedness of resources might reduce the uncertainty and increase the potential synergies and thus, enhance the foreign subsidiary's competitive advantage. Furthermore, we claimed that the transfer of knowledge and the parent firm's specific advantages can be facilitated in the case of greater parentsubsidiary resource relatedness, which has a positive impact on the performance of the subsidiary.

In terms of parent firm performance, we argued that resource relatedness can have both positive and negative effects. At high levels of resource relatedness, based on the resource-based and knowledge-based view literature, we claim that the benefits resulting from the efficient resource integration are large, which have a positive impact on the firm's performance. On the other hand, at a high level of resource dissimilarity, the parent firm can enjoy the potential benefits of economies of scope and complementary resources due to the fact that dispersion of knowledge in different industries enables the parent firm to develop novel technologies and generate efficient solutions which enhance its performance and more opportunity to discover, create, and exploit new capabilities.

\section{REFERENCES}

[1] Yang, Y., \& Driffield, N. (2012). Multinationality-Performance Relationship: A Meta-analysis. MIR: Management International Review, 52(1), 23-47.

[2] Contractor, F. J. (2007). Is international business good for companies? The evolutionary or multi-stage theory of internationalization vs. the transaction cost perspective. Management International Review, 47(3), 453-475.

[3] Wernerfelt, B. (1984). A resource-based view of the firm. Strategic $\begin{array}{lll}\text { Management } \quad \text { Journal, } & \text { 171-180. }\end{array}$ https://econpapers.repec.org/RePEc:bla:stratm:v:5:y:1984:i:2:p:171 180

[4] Tahami, H., Mirzazadeh, A., Arshadi-khamseh, A., \& GholamiQadikolaei, A., "A periodic review integrated inventory model for buyer's unidentified protection interval demand distribution," Cogent Engineering, 3(1), 1206689, 2016.

[5] Hitt, M. A., Hoskisson, R. E., \& Kim, H. (1997). International Diversification: Effects on Innovation and Firm Performance in Product-Diversified Firms. The Academy of Management Journal, 40(4), 767-798.

[6] Tahami, H., Mirzazadeh, A., \& Gholami-Qadikolaei, A., "Simultaneous control on lead time elements and ordering cost for an inflationary inventory-production model with mixture of normal distributions LTD under finite capacity," RAIRO-Operations Research vol. 53(4), pp. 1357-1384, 2019.

[7] Hamel, G. (1991). Competition for Competence and Inter-Partner Learning Within International Strategic Alliances. Strategic Management Journal, 12, 83-103.

[8] Capron, L., Mitchell, W., \& Swaminathan, A. (2001). Asset Divestiture Following Horizontal Acquisitions: A Dynamic View. Strategic Management Journal, 22(9), 817-844.

[9] Chang, S.-J., \& Rosenzweig, P. M. (2001). The Choice of Entry Mode in Sequential Foreign Direct Investment. Strategic Management Journal, 22(8), 747-776.

[10] Tahami, H., Rabadi, G., \& Haouari, M. (2020). Exact approaches for routing capacitated electric vehicles. Transportation Research Part E: Logistics and Transportation Review, 144, 102126.

[11] Barney, J. (1991). Firm Resources and Sustained Competitive Advantage. Journal of Management, 17(1), 99-120.

[12] Peng, M. W., \& Wang, D. Y. (2000). Innovation Capability and Foreign Direct Investment: Toward a Learning Option Perspective. MIR: Management International Review, 40(1), 79-93. 
[13] Tahami, H., \& Fakhravar, H., "Multilevel Reorder Strategy-based Supply Chain Model," 5th North American Conference on Industrial Engineering and Operations Management (IEOM), Michigan, USA, $2020 \mathrm{~b}$

[14] Luo, Y. (2003). Market-Seeking MNEs in an Emerging Market: How Parent-Subsidiary Links Shape Overseas Success. Journal of International Business Studies, 34(3), 290-309.

[15] Peltokorpi, V. (2015). Corporate Language Proficiency and Reverse Knowledge Transfer in Multinational Corporations: Interactive Effects of Communication Media Richness and Commitment to Headquarters. Journal of International Management, 21(1), 49-62.

[16] Björkman, I., Barner-Rasmussen, W., \& Li, L. (2004). Managing Knowledge Transfer in MNCs: The Impact of Headquarters Control Mechanisms. Journal of International Business Studies, 35(5), 443455.

[17] Collis, D., Young, D., \& Goold, M. (2007). The Size, Structure, and Performance of Corporate Headquarters. Strategic Management Journal, 28(4), 383-405.

[18] Egelhoff, W. G. (2010). How the Parent Headquarters Adds Value to an MNC. Management International Review, 50(4), 413-431.

[19] Rabbiosi, L. (2011). Subsidiary roles and reverse knowledge transfer: An investigation of the effects of coordination mechanisms. Journal of International Management, 17(2), 97-113.

[20] Ambos, T. C., \& Birkinshaw, J. (2010). Headquarters' Attention and Its Effect on Subsidiary Performance. Management International Review, 50(4), 449-469.
[21] Gaur, A. S., \& Lu, J. W. (2007). Ownership Strategies and Survival of Foreign Subsidiaries: Impacts of Institutional Distance and Experience. Journal of Management, 33(1), 84-110.

[22] Dellestrand, H. (2011). Subsidiary embeddedness as a determinant of divisional headquarters involvement in innovation transfer processes. Journal of International Management, 17(3), 229-242.

[23] Geleilate, J. M., Magnusson, P., Parente, R., \& Alvarado-Vargas, M. (2016). Home Country Institutional Effects on the MultinationalityPerformance Relationship: A Comparison Between Emerging and Developed Market Multinationals. Journal of International Management, 22, 380-402.

[24] Yahoodik, S., Tahami, H., Unverricht, J., Yamani, Y., Handley, H., \& Thompson, D. (2020). Blink Rate as a Measure of Driver Workload during Simulated Driving. Proceedings of the Human Factors and Ergonomics Society Annual Meeting, 64(1), 1825-1828.

[25] Tahami, H., \& Fakhravar, H., "A Fuzzy Inventory Model Considering Imperfect Quality Items with Receiving Reparative Batch and Order," European Journal of Engineering and Technology Research, vol 5(10), pp. 1179-1185, 2020

[26] Tahami, H., \& Fakhravar, H. (2020). A fuzzy inventory model considering imperfect quality items with receiving reparative batch and order overlapping. arXiv preprint arXiv:2009.05881. 